Australian Journal of
Crop Science

AJCS 14(11):1701-1706 (2020)

ISSN:1835-2707

doi: 10.21475/ajcs.20.14.11.p1407

\title{
Production and quality of watermelon grown under seaweed extract
}

\author{
Antonio Francisco de Mendonça Júnior ${ }^{1 *}$, Ana Paula Medeiros dos Santos Rodrigues ${ }^{1}$, Rui Sales Jr. ${ }^{2}$, \\ Andréia Mitsa Paiva Negreiros ${ }^{2}$, Marcos Oliveira Bettini ${ }^{3}$, Esdras de Oliveira França Júnior ${ }^{1}$, Álvaro Carlos \\ Gonçalves Neto ${ }^{1}$, Ranoel José de Sousa Gonçalves ${ }^{4}$, Kevison Rômulo da Silva França ${ }^{4}$
}

\author{
${ }^{1}$ Rural Federal University of Pernambuco (UFRPE), Brazil \\ ${ }^{2}$ Rural Federal University of Semiarid (UFERSA), Brazil \\ ${ }^{3}$ Acadian Seaplant, Brazil \\ ${ }^{4}$ Federal University of Campina Grande (UFCG), Brazil
}

*Corresponding author: antonio.mendoncajunior@ufrpe.br

\begin{abstract}
The use of biofertilizers with macroalgae base has become a viable alternative to conventionally used synthetic fertilizers. Among the advantages of using these extracts is the increase in productivity and improvements in the agronomic performance of the crop. Its use is allowed in organic agriculture as it is a natural product. The objective of this research was to evaluate the influence of the seaweed extract, Ascophyllum nodosum (L.) to the productive development and quality of watermelon plants. A randomized block design with 6 treatments and 4 replications was applied. The treatments comprised of full or divided doses (total of $3.0 \mathrm{ml} \mathrm{L}^{-1}$ ) of seaweed extract (T1: producer standard; T2: $\left(1.0-1.0-1.0 \mathrm{~mL} \mathrm{~L}^{-1}\right)$ applied 2 - 16 - 30 days after transplanting (d.a.t.); T3: (1.5 - 1.5 $\left.\mathrm{ml} \mathrm{L}^{-1}\right) 2$ - 30 (d.a.t.); T4: $\left(1.0-1.0-1.0 \mathrm{~mL} \mathrm{~L}^{-1}\right) 16-30$ - 44 (d.a.t.); T5: $\left(1.5-1.5 \mathrm{~mL} \mathrm{~L}^{-1}\right) 16$ - 30 (d.a.t.) T6: (3.0 mL L $\left.{ }^{-1}\right) 2$ (d.a.t.). 100 $\mathrm{mL}$ of the prepared solution was used for each experiment. The application of Acadian ${ }^{\circledR}$ improved the yield of water melon in the order of 12.69 to $27.76 \%$ and at different periods of the crop cycle.
\end{abstract}

Keywords: Ascophyllum nodosum (L.); Biofertilizers; Citrillus lanatus; Olericulture.

Abbreviations: PH_Plant height; FWAP_Fress weight of aerial part; RL_Redicular length; RV_Root volume; FWRS_Fresh weight of

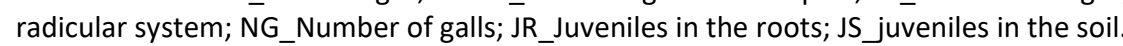

\section{Introduction}

Watermelon is one of the main olericulture species cultivated in Brazil, standing out as a product of great importance for the agribusiness of the country. It occupies the 8th position in the ranking of the most exported fruits in 2009yielding about $\$ 12.4$ million, with $28,261.7$ tons exported (IBRAF, 2014). The production in the country is distributed among the Northeast, South and North regions, being the first and main producer, responsible for over $34 \%$ of the national production. The states of Bahia (338,365 $t$ ), Pernambuco $(103,615 \mathrm{t})$ and Rio Grande $(76,872 \mathrm{t})$ are the largest states producers (IBGE, 2013).

In the state of Rio Grande do Norte, in the Mossoró-Assú region, the watermelon stands out as most produced and exported crop. It has become a routine agricultural practice for small, medium and large companies that send their production to large markets such as CEAGESP-SP and to the external markets (Torres, 2007).

Improving cultivation techniques or introducing new technologies can result in a better agronomic performance of a cultivated species. In this context, the techniques that can reduce the costs and maintain the ideal physiological and productive characteristics of watermelon has an extreme significance for the northeast region in Brazil, in which despite adequate edaphoclimatic characteristics for the crop development, it has high cost of agricultural inputs and lack of good crop traits (Andrade Júnior et al., 2006).

The consumer market is increasingly demanding for healthier foods, free of pesticides and fertilizers. Therefore studies should be carried out to develop new technologies that reduce the use of agricultural inputs, and provide improvements to the physical, chemical and biological soil characteristics, in addition to maintaining a good production and quality of the fruits (Mesquita et al., 2007). In this context, use of macroalgae as a biofertilizer is a distinct alternative from chemical inputs.

The macroalgae has nutrients, amino acids, vitamins, cytokinins, auxins and abscisic acid (ABA) in their composition that act as plant development promoters (Stirk et al., 2003). Application of marine algae has direct influence on plant protection against phytopathogens, and also promotes the production of bioactive molecules capable to induce resistance in plants (Stadnik and Talamini, 2005). The species Ascophyllum nodosum (L.) Le Jolis is the most researched in the agriculture (Ugarte et al., 2006). The extract stimulates plant growth due to its rich composition in macro and micronutrients, carbohydrates, amino acids, and plant hormones specific to algae (Martins, 2006). 
Commercial products based on A. nodosum (L.) seaweed extract, such as Acadian $^{\circledR}$, present 13.0 to $16.0 \%$ organic matter, $1.01 \%$ amino acids (alanine, aspartic and glutamic acid, glycine, isoleucine, leucine, lysine, methionine, phenylalanine, proline, tyrosine, tryptophan and valine), carbohydrates, and concentrations of nutrients $\mathrm{N}, \mathrm{P}, \mathrm{K}, \mathrm{Ca}$, $\mathrm{Mg}, \mathrm{S}, \mathrm{B}, \mathrm{Fe}, \mathrm{Mn}, \mathrm{Cu}$ and $\mathrm{Zn}$. They also present growth hormones (auxins, gibberellins, cytokinins, abscisic acid), resistance elicitors and micronutrient transport aids, which stimulate plant growth and improve fruit quality (Acadian , 2009).

In several regions of the world, algaes have been used to increase productivity and food production, due to their beneficial effects, when applied to the crops.

According to Mazzarino and Bortolossi (2010) the use of algae extract $A$. nodosum (L.) in cucumber significantly increased fruit uniformity and quantity. However, no significant difference was obtained for fruit weight, length and diameter among tested the treatments. Oliveira et al. (2011), applied the algae extract, $A$. nodosum (L.) on the production of yellow passion fruit seedlings and verified that dose of $4 \mathrm{~mL} \mathrm{~L}^{-1}$ of the product Acadian ${ }^{\circledR}, A$. nodosum (L.), increased the height and number of leaves per plant.

Studies made by Oliari et al. (2013), proved that the use of algae extract applications in the dose of $6 \%$ of Acadian $^{\circledR}$, increased the productive and chemical aspects of the plum, cv. Pen 7, with higher ratio value which is an important characteristic in the fruit flavor.

The use of the extract of $A$. nodosum (L.) for commercial crops is highly demanded and more precise information needs to be generated. In this context, the objective of the present work was to evaluate the production and quality of watermelon treated with the commercial product of algae extract A. nodosum (L.), Acadian .

\section{Results and Discussion}

\section{Total number of fruits (NTF), Productivity (PROD) and Fresh fruit mass (MF)}

The effects of different intervals and application rates of the A. nodosum (L.) extract Acadian were observed for the productivity variables only. For the number of fruits and fresh mass, effects were not observed when submitted to the Dunnet test at the $5 \%$ probability level (Table 1 ).

However, the average mass verified for the watermelon fruits, Quetzali cultivar, is within the range considered suitable for commercialization in the foreign market, according to the seed company that affirm that the fruits can present fresh mass from 2.5 to $6 \mathrm{~kg}$. The results of this research corroborate with those found by Martins et al. (2013) and Almeida et al. (2010), after application of biostimulants on Quetzali type watermelons, where obtained averages of 3.97 and $3.84 \mathrm{~kg}$ of fruit, respectively. The total fruit yield is measured by the relation between the number of fruits and fresh mass. The result can be influenced by factors related to genetic material and crop management mainly. The similarity of the average values for the productivity between the different treatments can be justified, since the number of fruits produced and the average weight of the fruits did not differ as to the different periods of application and fractionation of the doses. Robinson and Decker-Walters (1997) commented that in cucurbitaceae the productivity depends on both the total number of fruits and the size of the fruit. However, crop densification provides a higher number of fruits and a lower average weight due to competition pressures between plants. For this research, there is no variation regarding the density between plants and rows.

According to Costa and Grangeiro (2010), the average productivity of the watermelon crop in the Northeast is between 20 and 45 tons ha ${ }^{-1}$. Thus, all treatments presented values of productivity within the range that comprises the regional average. Although $\mathrm{T} 1$, the producer's standard, presented lower productive results than the other treatments, with increments ranging from 12.69 to $27.76 \%$, when applied Acadian ${ }^{\circledR}$. Costa et al. (2013), found that the average number of fruits for the same cultivar, Quetzali, was higher than the one found in this study (1650-2170 ha ${ }^{-1}$ fruits). However, the average productivity was equivalent ( 55.47 tons $\mathrm{ha}^{-1}$ ). This can be justified by the increase promoted by the application of Acadian ${ }^{\circledR}$, since the extract of the algae $A$. nodosum (L.) promotes the development of fruits due to the increase in the availability of cytokinin, hormone related to the partition and mobilization of assimilates direction especially to these drains, when the plant is in the reproductive stage (Adam-Phillips et al., 2004; Khan et al., 2009). Nowdays, the extract of $A$. nodosum (L) is known as a inducer of endogenous cytokinin synthesis in plants by regulating the expression of genes related to this hormone, which may influence several plant parameters (Khan et al., 2011). The average weight of the fruits, is directly related to the size of the fruit (Table 2).

\section{Peel and pulp thickness (EC and EP)}

The thickness average found in the study $(1.84 \mathrm{~cm})$ can be considered thin, according to Lima Neto et al. (2010), indicating greater need for care in packaging. Watermelon production system is predominantly made in bulk, requiring a shell thickness that supports the fruit handling (Silva et al., 2007). The increase in the thickness of the peel is a desirable characteristic from the commercial point of view, since it means a greater resistance of the fruits to mechanical damages and improvement in the post-harvest life. The increase in the exocarp constitutes a natural barrier due to the deposition of the cuticle, which can contribute to the control of moisture loss and provide mechanical resistance to the tissue (Neinhuis, 2005).

Regarding the thickness of the pulp, no effect of Acadian ${ }^{\circledR}$ application was observed, either in an integral or fractional dose. However, the small thickness of the peel observed in the studied cultivar (Quetzali) can reduce the margin of response to external factors, as biostimulant application. The results corroborate with what was proposed by Karnok (2000), when he states that according to the variable the use A. nodosum (L.) extract can result in positive or negative responses and may not even cause significant changes. Thus, plants grown in a favorable environment to its development present less pronounced effects, different from environment under stress conditions (Long, 2006). The effect of different intervals and application rates of Acadian ${ }^{\circledR}$ was verified only for the variables, $\mathrm{pH}$, soluble solids, titratable acidity, and soluble solids ratio: titratable acidity. The same was observed for pulp firmness and total sugars when submitted to the Dunnet's test at the $5 \%$ probability level (Table 3 ). 
Table 1. Number of fruits average (NF), fresh weight (MF) and productivity (PROD) obtained as a function of the application interval (Al) (days after sowing) and whole or fractionated doses of Acadian ${ }^{\circledR}$ in watermelon. Mossoró - RN, 2015.

\begin{tabular}{|c|c|c|c|}
\hline Treatment: I.A. ${ }^{1}$; Dose ${ }^{2}$ & NF & $\begin{array}{l}\text { FW } \\
(\mathrm{Kg})\end{array}$ & $\begin{array}{c}\text { PROD } \\
\left(\text { Ton. ha }{ }^{-1}\right)\end{array}$ \\
\hline T1: Producer standard & $16904.51 a$ & $2.83 a$ & $47.86 b$ \\
\hline T2: $2-16-30$ (d.a.t. $)^{3} ;\left(1.0-1.0-1.0 \mathrm{~mL} \mathrm{~L}^{-1}\right)$ & $15900.17 a$ & $3.67 a$ & $57.70 a$ \\
\hline T3: $2-30$ (d.a.t.); $\left(1.5-1.5 \mathrm{~mL} \mathrm{~L}^{-1}\right)$ & $16639.32 a$ & $3.69 a$ & $61.36 a$ \\
\hline T4: $16-30-44$ (d.a.t.); $\left(1.0-1.0-1.0 \mathrm{~mL} \mathrm{~L}^{-1}\right)$ & $18281.25 a$ & $3.28 \mathrm{a}$ & $60.14 a$ \\
\hline T5: $16-30$ (d.a.t.); $\left(1.5-1.5 \mathrm{~mL} \mathrm{~L}^{-1}\right)$ & $16791.67 a$ & $3.92 a$ & $66.26 a$ \\
\hline T6: 2 (d.a.t.); $\left(3.0 \mathrm{~mL} \mathrm{~L}^{-1}\right)$ & $16250.00 a$ & $3.37 a$ & $54.82 \mathrm{a}$ \\
\hline C.V. (\%) & 14.72 & 18.39 & 23.19 \\
\hline
\end{tabular}

${ }^{1}$ I.A .: Application intervals of Acadian ${ }^{\oplus}$, via fertigation. ${ }^{2}$ Doses: Fractionation of the $3 \mathrm{~mL} \mathrm{~L}^{-1}$ Acadian ${ }^{\oplus}$ dose. Application of $100 \mathrm{~mL}$ of the solution per plant. ${ }^{3}$ d.a.t .: Days after transplanting. Averages followed by the same letters in the columns do not differ by Dunnet's test at the $5 \%$ probability level.

Table 2. Average data on peel and pulp thickness obtained from application interval (days after sowing) and whole or fractionated doses of Acadian ${ }^{\circledR}$ in watermelon plants. Mossoró - RN, 2015.

\begin{tabular}{lcc}
\hline Treatments: A.I. ${ }^{1}$ Dose $^{2}$ & Peel thickness & Pulp thickness \\
\hline T1: Producer standart & $1.675 \mathrm{~b}$ & $14.625 \mathrm{a}$ \\
T2: $2-16-30$ (d.a.t.) ${ }^{3} ;\left(1.0-1.0-1.0 \mathrm{~mL} \mathrm{~L}^{-1}\right)$ & $1.762 \mathrm{~b}$ & $13.662 \mathrm{a}$ \\
T3: $2-30$ (d.a.t.); $\left(1.5-1.5 \mathrm{~mL} \mathrm{~L}^{-1}\right)$ & $1.900 \mathrm{~b}$ & $14.962 \mathrm{a}$ \\
T4: $16-30-44$ (d.a.t.); $\left(1.0-1.0-1.0 \mathrm{~mL} \mathrm{~L}^{-1}\right)$ & $1.850 \mathrm{~b}$ & $15.287 \mathrm{a}$ \\
T5: $16-30$ (d.a.t.); $\left(1.5-1.5 \mathrm{~mL} \mathrm{~L}^{-1}\right)$ & $2.050 \mathrm{a}$ & $14.100 \mathrm{a}$ \\
T6: 2 (d.a.t.); (3.0 $\left.\mathrm{mL} \mathrm{L}^{-1}\right)$ & $1.850 \mathrm{~b}$ & $15.262 \mathrm{a}$ \\
\hline C.V. $(\%)$ & 10.97 & 8.80
\end{tabular}

${ }^{1}$ A.I.: Application intervals of Acadian ${ }^{\circledast}$, via fertigation. ${ }^{2}$ Doses: Fractionation of the $3 \mathrm{~mL}$ L-1 Acadian ${ }^{\otimes}$ dose. Application of $100 \mathrm{~mL}$ of the solution per plant. ${ }^{3}$ d.a.t.$:$ Days after transplanting. Averages followed by the same letters in the columns do not differ by Dunnet's test at the $5 \%$ probability level.

Table 3. Average values of pulp firmness (PF), hydrogenation potential (pH), total sugars (TS), soluble solids (SS), titratable acidity (TA) and soluble solids ratio:titratable acidity (SS / TA) (AI) (days after sowing) and whole or fractionated doses of Acadian ${ }^{\circledR}$ in watermelon plants. Mossoró - RN, 2015.

\begin{tabular}{|c|c|c|c|c|c|c|}
\hline \multirow[t]{2}{*}{ Treatements: I.A. ${ }^{1}$; Dose ${ }^{2}$} & PF & $\mathrm{pH}$ & TS & SS & TA & SS/TA \\
\hline & $(\mathrm{N})$ & & (\%) & & $\left(\mathrm{mmol} \mathrm{H}+100 \mathrm{~mL}^{-1}\right)$ & \\
\hline T1: Producer standart & $8.065 a$ & $5.780 \mathrm{a}$ & $6.373 a$ & $10.812 a$ & $0.182 \mathrm{a}$ & $59.788 \mathrm{~b}$ \\
\hline T2: $2-16-30$ (d.a.t. $)^{3} ;\left(1.0-1.0-1.0 \mathrm{~mL} \mathrm{~L}^{-1}\right)$ & $8.204 a$ & $5.642 a$ & $5.668 a$ & $9.962 b$ & $0.126 b$ & $79.760 a$ \\
\hline T3: $2-30$ (d.a.t.); $\left(1.5-1.5 \mathrm{~mL} \mathrm{~L}^{-1}\right)$ & 7.787a & $5.722 \mathrm{a}$ & $6.416 a$ & $10.450 a$ & $0.127 \mathrm{~b}$ & $82.390 a$ \\
\hline T4: $16-30-44$ (d.a.t.); $\left(1.0-1.0-1.0 \mathrm{~mL} \mathrm{~L}^{-1}\right)$ & $7.996 a$ & $5.670 a$ & $5.053 a$ & $9.912 b$ & $0.144 b$ & $69.038 \mathrm{~b}$ \\
\hline T5: $16-30$ (d.a.t.); $\left(1.5-1.5 \mathrm{~mL} \mathrm{~L}^{-1}\right)$ & $7.787 a$ & $5.635 b$ & $5.346 a$ & $10.137 a$ & $0.166 a$ & $61.274 b$ \\
\hline T6: 2 (d.a.t.); $\left(3.0 \mathrm{~mL} \mathrm{~L}^{-1}\right)$ & $8.760 a$ & $5.755 a$ & $5.740 \mathrm{a}$ & $10.237 a$ & $0.154 a$ & $66.430 \mathrm{~b}$ \\
\hline C.V. (\%) & 17.62 & 1.25 & 11.98 & 3.82 & 10.67 & 8.20 \\
\hline
\end{tabular}

${ }^{1}$ I.A .: Application intervals of Acadian ${ }^{\oplus}$, via fertigation. ${ }^{2}$ Doses: Fractionation of the $3 \mathrm{~mL} \mathrm{~L}^{-1}$ Acadian ${ }^{\oplus}$ dose. Application of $100 \mathrm{~mL}$ of the solution per plant.

${ }^{3}$ d.a.t .: Days after transplanting. Averages followed by the same letters in the columns do not differ by Dunnet's test at the $5 \%$ probability level.

Table 4. Extract of Ascophyllum nodosum (L.), Acadian ${ }^{\circledR}$ applied in watermelon cv. 'Quetzali' in different periods of application and fractionation of doses. Mossoró - RN, 2015.

\begin{tabular}{cll}
\hline Treatments $^{1}$ & Aplication intervals & Doses $\left(\mathrm{L} \mathrm{ha}^{-1}\right)$ \\
\hline T1 & Producer standard & Producer standard \\
T2 & $2-16-30$ (d.a.t.) & $\left(1.0-1.0-1.0 \mathrm{~mL} \mathrm{~L}^{-1}\right)$ \\
T3 & $2-30$ (d.a.t.) & $\left(1.5-1.5 \mathrm{~mL} \mathrm{~L}^{-1}\right)$ \\
T4 & $16-30-44$ (d.a.t.) & $\left(1.0-1.0-1.0 \mathrm{~mL} \mathrm{~L}^{-1}\right)$ \\
T5 & $16-30$ (d.a.t.) & $\left(1.5-1.5 \mathrm{~mL} \mathrm{~L}^{-1}\right)$ \\
T6 & 2 (d.a.t.) & $\left(3.0 \mathrm{~mL} \mathrm{~L}^{-1}\right)$ \\
${ }^{1}$ T1: producer standart; T2, T3, T4, T5, T6: producer standart + Acadian ${ }^{\oplus}$ application in different periods and fractionation of doses. ${ }^{2}$ Day after transplanting.
\end{tabular}

The exception for pulp firmness, $8.094 \mathrm{~N}$, all the others average values found for physicochemical variables, are within the range considered adequate. From the physical aspects of the fruit, the firmness of the pulp is also one of the determining characteristics for fruit shelf life (Menezes et al., 2001). According to Araújo Neto, et al. (2000), the firmness of the pulp should vary between 9.00 and $16.00 \mathrm{~N}$ for watermelon to reach the European shelves with good postharvest conservation. Almeida et al. (2010) in studied Crimson Sweet and Quetzali watermelon in Mossoro-Assu, and reported that the minimum firmness value should be between $12.6 \mathrm{~N}$ and $15 \mathrm{~N}$ at the time of harvest. Low firmness of the fruit pulp is related to the loss of membrane integrity of the mesocarp cells and to the degradation of the polymeric constituent molecules of the cell wall, such as cellulose, hemicellulose and pectin, which generate changes, leading to pulp softening (Pinto et al., 2010). Thus, products with biostimulant action, such as $A$. nodosum (L.) extracts, applied at the pre-harvest stage can influence the postharvest characteristics, since they have compounds such as betaine. These are substances that can stabilize the cell membrane and increase the tolerance to stress avoiding the collapse caused by the loss of water from the cell (Silva, 2011; Castro et al., 2011). 


\section{Hydrogen ionic potential (pH)}

For the hydrogenation potential $(\mathrm{pH})$ only $\mathrm{T} 5(5,635)$ differed from the producer standard $(5,780)$. Watermelon $\mathrm{pH}$ values similar to those found in this research can be verified on Lima Neto et al. (2010) (5.18-5.49) and Martins et al. (2013) (5.14 - 5.25) studies. From what was expected, there was no association of the highest titratable acidity with the lowest $\mathrm{pH}$ in the fruit pulp of both cultivars. However, the environmental factors, as well as the management and the degree of maturation at the time of harvest influenced the chemical composition of the watermelon. In general, fruits with higher titratable acidity also showed higher $\mathrm{pH}$.

\section{Titratable acidity (TA)}

A different effect on the titratable acidity of the fruits was observed according to the application of biostimulant. The fruits from plants that received application of Acadian ${ }^{\circledR}$ presented different behavior for accumulation of acidity of the fruits, in which the titratable acidity presented higher on fruits from plants that did not receive application or received in more spaced periods. This indicates that the application of this product stimulated the synthesis of organic acids in a differentiated way as a substance with cytokinin-like effect, may influence the physiology of the fruit (Souza Leão et al., 2005).

From the industrial point of view, Cavichioli et al. (2008) stated that the high titratable acidity content decreases the need for addition of acidifiers in passion fruit juice, fruit in which citric acid is also the most accumulated acid. According to Chitarra and Chitarra (2005), the buffer capacity of some juices allows large variations in titratable acidity to occur, with no appreciable variations in $\mathrm{pH}$.

For Durigan and Mattiuz (2007), the minimum soluble solids content recommended for watermelon is $10 \%$. On the other hand, these values are above the range (6.88 and 9.07\%) found in watermelon by Almeida et al. (2010) and Ramos et al. (2009). However, the spatial distribution of the soluble solids content in the pulp is varied (Leão et al., 2006), being larger in the central region, with gradual reduction as it approaches the shell. In the present study, the soluble solids content was considered adequate (10.257\%), even though it was determined in juice from the mixture of different parts of the pulp. Also in observation, the higher dose fractions promoted a reduction in soluble solids content.

\section{Soluble Solids / Titratable Acidity (SS / AT)}

The SS:AT ratio provides a good evaluation of the fruit flavor, being more representative than the measurement of sugars and acidity. Treatments 2 and 3 stood out with a higher value of the SS:AT ratio, presenting a statistical difference at the $5 \%$ probability level when compared to other treatments, including the producer's standard (without application of Acadian $^{\circledR}$ ).

The results showed fruits with SS:AT ratio up to 82.390 . High value of this ratio is an indication of excellent combination of sugars and acidity, characterizing soft-tasting fruits. This condition, however, can be confused in fruits with low levels of SS and AT, which will result in a high SS: AT ratio, but with flavor considered tasteless (Chitarra, 2005).

The SS: AT ratio values found in this study were above those presented by Grangeiro and Cecílio Filho (2004), evaluating the hybrid Tide ( 48.2 to 47.2 ), what can be explained by the low acidity presented in these two treatments, with 0.126 and $0.127 \mathrm{~g}$ of citric acid, $100 \mathrm{~mL}^{-1}$ of juice. The probable lack of nutritional balance adjustments of the plants in the growing conditions of Mossoró, RN, can contribute to lower SS:AT ratio and, and consequently, the fruit flavor.

\section{Materials and Methods}

The experiment was set up in melon production area, experimental field, obeying the experimental design in randomized blocks, with six treatments and four replicates (Table 4).

The treatments consisted of the application of the $3.0 \mathrm{~mL} \mathrm{~L}^{-1}$ dose of Ascophyllum nodosum (L.) extract implemented in complete or fractionated doses as a function of periods of application. The treatments were defined as follows: T1: Producer standard or control treatment, which corresponded to the manner in which the product was administered on the farm, where the study was performed. T2: application performed at 2 - 16 - 30 days after transplantation (d.a.t.) with fractionated dose in applications of $1.0-1.0-1.0 \mathrm{~mL} \mathrm{~L}^{-1} ; \mathrm{T3}$ : application performed at $2-30$ (d.a.t.) with fractionated dose in applications of $1.5-1.5 \mathrm{~mL}$ $\mathrm{L}^{-1}$; T4: application performed at $16-30-44$ (d.a.t.) with fractionated dose in applications of $1,0-1,0-1,0 \mathrm{~mL} \mathrm{~L}^{-1} ; \mathrm{T}$ : application performed at 16 - 30 (d.a.t.) with fractionated dose in applications of $1.5-1.5 \mathrm{~mL} \mathrm{~L}^{-1}$ and T6: application at 2 (d.a.t.) with application of full dose of $3.0 \mathrm{~mL} \mathrm{~L}^{-1}$.

The spacing used was $2.0 \times 0.4 \mathrm{~m}$, with each 10 plants by parcel. The experimental area presented a total of 96.0 linear meters ${ }^{-1}$.

Watermelon seeds Quetzali type were seeded in expanded polystyrene trays with 128 cells and supplemented with Pole ${ }^{\circledR}$ organic compound.

Seedlings were transplanted to the field after eight days of sowing. The transplant was carried out under double-sided "mulch" plastic cover, with the upper side white and black inside. After transplantation, the seedlings were covered with a non-woven cloth, with a grammage of $15 \mathrm{~g} / \mathrm{m}^{2}$, remaining until for 28 days.

For the experiment, all the management practices and usual cultural practices for the cultivation of the crop in Rio Grande do Norte were adopted, with soil preparation, plowing and harrowing, followed by row routing, spaced by $2,0 \mathrm{~m}$ and $20 \mathrm{~cm}$ of depth approximately.

The irrigation system used was high frequency (drip), with emitters spaced $0.40 \mathrm{~m}$ apart, with a pressure range of 1.5 $\mathrm{kgf} \mathrm{cm}^{-2}$ and $3.5 \mathrm{~L} \mathrm{~h}^{-1}$ flow, specified by the manufacturer. The irrigation shift was carried out daily according to the need of the crop for the region.

Harvest time was carried out at 75 days after sowing, and also for each parcel the number of fruits was counted, using the standard market size. Two fruits of each plot were collected for analysis, being eight fruits per treatment.

On the same day of harvest, watermelon fruits were evaluated for the following physical characteristics: total number of fruits per parcel (NTF); Fruit type (TF); Productivity (PROD) (t ha $\left.{ }^{-1}\right)$; Fresh fruit weight (MFF) (g); Fruit length (CF) $(\mathrm{cm})$; Fruit diameter (DF) $(\mathrm{cm})$; Peel thickness (EC) (cm); Pulp thickness (EP) $(\mathrm{cm})$ and firmness of the pulp (FP). Edible fraction (pulp) was removed from the fruit with a stainless steel knife, which was homogenized in a blender and placed in $50 \mathrm{ml}$ falcon tubes to perform the chemical evaluations: soluble solids content (TSS) ; Titratable acidity (TA); Hydrogenation potential $(\mathrm{pH})$ and total sugars (ACT). 


\section{Total number of fruits (NTF)}

This value was obtained by counting the number of fruits from the useful area of the plot, being converted to number of fruits per hectare.

\section{Productivity (PROD)}

This value was obtained by weighing the commercial fruits of the useful area from each treatment, considering the commercial quality standards fruits, genetating a estimative of yield in $\mathrm{tha}^{-1}$.

\section{Fresh fruit mass (MF)}

This characteristic was determined by the individual weighing of eight fruits / treatment with a precision scale, with the results expressed in gram (g).

\section{Peel and pulp thickness (EC and EP)}

The thickness of the pulp was obtained by dividing the fruit lengthwise into two parts, from which the endocarp thickness was measured on each side with a digital caliper. The mean value for eight fruits per treatment was obtained. The thickness of the peel was measured by measuring the distance between the epicarp (shell) and the mesocarp, using a digital caliper, determined in eight fruits / treatment. All results determined in centimeters $(\mathrm{cm})$.

\section{Firmness of the pulp (FP)}

In order to obtain pulp firmness data, the fruits were cut longitudinally, and equidistant reading was performed in each of the equatorial half of the melon fruits (two readings per fruit). Eight fruits per treatment were used. A penetrometer Fruit Pressure Tester TR type FT 327 (3-27 Lbs.) was used, with a conical tip probe of eight (8) $\mathrm{mm}$ diameter. The results obtained in pounds were converted to Newton (N), multiplying the value by the conversion factor 4.45 (Gomes Júnior et al., 2001).

\section{Hydrogen ionic potential (pH)}

The $\mathrm{pH}$ was determined with a Tecnopon pHmetrer, model mPA-210, with automatic temperature adjustment, duly standardized with buffer solutions $\mathrm{pH} 7.0$ and $\mathrm{pH}$ 4.0. Aliquots of $5 \mathrm{~g}$ of the fruit extract were diluted in $50 \mathrm{~mL}$ of distilled water. The measured data were expressed in real $\mathrm{pH}$ values (AOAC, 2002).

\section{Soluble solids content (SS)}

Solvent solids contents were obtained using a digital refractometer model IPDBR45, with automatic temperature compensation ( 0 to $45 \%$ scale), and two juice samples were evaluated per repetition. The juice was obtained as described in item 2.3. The results are expressed as a percentage (\%).

\section{Titratable acidity (TA)}

This variable was determined in duplicate, obtained by titration of the melon juice where a solution of $0.1 \mathrm{~N} \mathrm{NaOH}$ was added, according to the methodology of the Adolfo Lutz
Institute (1985). The results were expressed as percentage (\%) of citric acid.

\section{Soluble Solids / Titratable Acidity (SS / AT)}

The SS/AT ratio was obtained by the quotient between the values of soluble solids and titratable acidity, and the results were expressed as a percentage (\%).

\section{Total sugars (ACT)}

Sugar was determined by the method of Antrona ( $\mathrm{C} 4 \mathrm{H} 100)$, according to Yemn and Willis (1954). The extract was obtained through aliquots of $0.5 \mathrm{~g}$ of each sample, diluted in a $100 \mathrm{~mL}$ volumetric flask, and then filtered in qualitative Wathman paper No. 1.

Subsequently, a $50 \mu \mathrm{L}$ aliquot of the extract and $95 \mu \mathrm{L}$ of distilled water were taken and placed in a test tube. The tubes were placed in an ice bath and the anthrone reagent was added to be agitated and brought to boiling water bath for 8 minutes and then cooled in ice water to room temperature. The reading was realized in a spectrophotometer at $620 \mathrm{~nm}$. The concentration readings were done in triplicates, from which the average between them was extracted. The results were expressed as $\mathrm{g} / 100 \mathrm{~g}$ of watermelon pulp.

\section{Statistical analysis of data}

The data obtained in this experiment were submitted to analysis of variance for the characteristics evaluated using statistical software ASSISTAT, version 7.7 Beta (Silva and Azevedo, 2009). In the cases where the treatment data presented significant differences, the $\mathrm{F}$ test was applied to the $5 \%$ probability level. The mean test was used to compare the means, at the $5 \%$ probability level.

\section{Conclusion}

Acadian ${ }^{\circledR}$ seed treatment and the application of 3 and $L^{-1}$ doses were efficient in the production of watermelon seedlings. The watermelon plants submitted to applications at intervals 7, 10 and 14 days were superior to those that did not receive application, independently of the seed treatment. Acadian ${ }^{\circledR}$ application during different crop cycle periods under different dose fractions, promoted increases in fruit yield in the order of 12.69 to $27.76 \%$. The application of Acadian $^{\circledast}$ promoted significant differences in the physicochemical variables evaluated. Presenting different behavior observed among different doses fractions.

\section{References}

Acadian Agritech (2009) Plant science: Science and Sustainability. Acadian Agritech, Cornwallis, Nova Scotia, Canada.

Adams-Phillips L, Barry C, Giovannoni J (2004) Signal transduction systems regulating fruit ripening. Trends in Plant Science. 9: 331338.

Adolf Lutz Institute (1985) Normas analíticas do Instituto Adolfo Lutz: Métodos químicos e físicos para análise de alimentos. 2nd edn. São Paulo: Instituto Adolfo Lutz, Brasil 533p.

Almeida MLB, Silva GG, Rocha RHC, Morais PLD, Sarmento JDA (2010) Caracterização físico-química de melancia 'Quetzali' durante o desenvolvimento. Revista Caatinga. 23(4): 28-31.

Andrade Júnior AS, Dias NS, Figueiredo Júnior LGM, Ribeiro VQ, Sampaio DB (2006) Produção e qualidade de frutos de melancia à aplicação de nitrogênio via fertirrigação. Revista Brasileira de Engenharia Agrícola e Ambiental. 10(4): 836-841. 
AOAC. Association of Official Analytical Chemists (2002) Official methods of analysis of AOAC international. 17rd. edn. Washington. 58.

Araújo Neto SE, Hafle OM, Gurgel FL, Menezes JB, Silva GG (2000) Qualidade e vida útil pós-colheita de melancia Crimson Sweet, comercializada em Mossoró. Revista Brasileira de Engenharia Agrícola e Ambiental. 4(2): 235-239.

Bargel H, Neinhuis C (2005) Tomato (Lycopersicon esculentum Mill.) fruit growth and ripening as related to the biomechanical properties of fruit skin and isolated cuticle. Journal of Experimental Botany. 56(413): 1049-1060.

Castro PRC, Macedo WR, Serciloto CM (2011) Agroquímicos de controle hormonal na agricultura tropical. In: Série Produtor Rural, Piracicaba: ESALQ - Divisão de Biblioteca e Documentação, 2011. 150p.

Cavichioli JC, Ruggiero C, Volpe CA (2008) Caracterização físicoquímica de frutos de maracujazeiro-amarelo submetidos à iluminação artificial, irrigação e sombreamento. Revista Brasileira de Fruticultura. 30(3) 649-656.

Chitarra MIF, Chitarra AB (2005) Pós-colheita de frutas e hortaliças: fisiologia e manuseio. 2nd edn. Universidade Federal de Lavras, Lavras, Minas Gerais, Brasil. 785p.

Costa ARFC, Medeiros JF, Porto Filho FQ, Silva JS, Costa FGB, Freitas DC (2013) Produção e qualidade de melancia cultivada com água de diferentes salinidades e doses de nitrogênio. Revista Brasileira de Engenharia Agrícola e Ambiental. 17(9): 947-954.

Costa ND, Grangeiro LC (2010) Sistemas de Produção. In: Embrapa Semiárido (ed). Sistemas de Produção - Versão eletrônica, 5, Petrolina, Brasil.

Crozier A, Kamiya Y, Bishop G, Yokota T (2010) Biosynthesis of hormones and elicitor molecules. In.: Buchanan BB, Grissen W, Jones RL (eds.). Biochemistry and Molecular Biology of Plants, American Society of Plant physiologists, Rockville, Maryland. 850894.

Durigan MFB, Mattiuz BH (2007) Injúrias mecânicas e seus efeitos na qualidade de melancias armazenadas em condição ambiente. Horticultura Brasileira. 25(2): 296-300.

Gomes Júnior J, Menezes JB, Nunes GHS, Costa FB, Souza PA (2001) Qualidade pós-colheita do melão tipo Cantaloupe, colhido em dois estádios de maturação. Horticultura Brasileira. 19(3): 356360.

Grangeiro LC, Cecílio Filho AB (2004) Qualidade de frutos de melancia em função de fontes e doses de potássio. Horticultura Brasileira. 22(3): 647-650.

IBRAF. Instituto Brasileiro de Frutas (2014). In: Embrapa Semiárido (ed). Alerta de exportação: vencendo as atuais barreiras fitossanitárias de mercados potenciais - prioridades para negociações internacionais. 2014. 203p.

IBGE. Instituto Brasileiro de Geografia e Estatística (2013) Produção Agrícola municipal: Culturas temporárias e permanentes. 2013. 99p.

Karnok KJ (2000) Promises, promises: can biostimulants deliver? Golf Course Management. Newton. 68: 67-71.

Khan W, Hiltz D, Critchley AT, Prithiviraj B (2011) Bioassay to detect Ascophyllum nodosum extract-induced cytokinin-like activity in Arabidopsis thaliana. Journal of Applied Phycology. 23(1): 409414.

Khan W, Menone U, Subramanian S (2009) Seaweed extracts as biostimulants of plant growth and development. Jornal Plant growth Regulation. 28(4): 386-399.

Leão DS, Peixoto JR, Vieira JV (2006) Teor de licopeno e de sólidos solúveis totais em oito cultivares de melancia. Bioscience Journal. 22(3): 7-15.

Lima Neto IS, Guimarães IP, Batista PF, Aroucha EMM, Queiróz MA (2010) Qualidade de frutos de diferentes variedades de melancia provenientes de Mossoró-RN. Revista Caatinga. 23(4): 14-20.
Long $E$ (2006) The importance of biostimulants in turfgrass management[Online]. Available www.golfenviro.com/biostimulants_(_roots_).htm.

Martins DA (2006) Uso de extratos à base de algas para controlar a antracnose (Colletotrichum lindemuthianum) e a ferrugem (Uromyces appendiculatus) do feijoeiro. 2006. 41f. Monografia (Bacharelado em Agronomia) - Centro de Ciências Agrárias Universidade Federal de Santa Catarina. Florianópolis, 41p.

Martins JCP, Aroucha EMM, Medeiros JF, Nascimento IB, De Paula, VFS (2013) Características pós-colheita dos frutos de cultivares de melancia, submetidas à aplicação de bioestimulante. Revista Caatinga. 26(2): 18-24

Mazzarino SA, Bortolossi JL (2010) Eficiência agronômica da alga Ascophyllum nodosum, no acréscimo de produtividade e qualidade na produção da cultura do pepino. Revista Brasileira de Energias Renováveis. 1(1): 148-161.

Menezes JB, Gomes Júnior J, Araújo Neto SE, Simões AN (2001) Armazenamento de dois genótipos de melão Amarelo sob condições ambiente. Horticultura Brasileira. 19(1): 42-49.

Mesquita EF, Cavalcante LF, Gondim SC, Cavalcante IHL, Araújo FAR, Beckmann-Cavalcante MZ (2007) Produtividade e qualidade de frutos do mamoeiro em função de tipos e doses de biofertilizantes. Semina: Ciências Agrárias. 28(4): 589-596.

Oliari ICR, Hennerich JE, Sato AJ, Faria CMDR, Botelho RV (2013) Extrato de algas na produção e qualidade de ameixeiras cv. Pluma 7. Cadernos de Agroecologia. 8(2): 01-04.

Oliveira LAA, Góes GB, Melo IGB, Costa ME, Silva RM (2011) Uso do extrato de algas (Ascophyllum nodosum) na produção de mudas de maracujazeiro-amarelo. Revista Verde. 6(2): 01-04.

Pinto PM, Jacomino AP, Cavalini FC, Cunha Júnior LC, Inouell KN (2010) Estádios de maturação de goiabas 'Kumagai' e 'Pedro Sato' para o processamento mínimo. Ciência Rural. 40(1): 37-43.

Ramos ARP, Dias RCS, Aragão CA (2009) Densidade de plantio na produtividade e qualidade de frutos de melancia. Horticultura Brasileira. 27(4): 560-564.

Robinson RW, Decker-Walters DS (1997) Cucurbits. New York: CAB International, 226p.

Salisbury FB, Ross CW (2012) Fisiologia das plantas. São Paulo: Cengage Learning, p.391-393.

Silva FAS, Azevedo CAV (2009) Principal components analysis in the software Assistat- Statistical Attendance. Paper presented at the 7th World Congress on Computers in Agriculture, Reno - NV, 22 24 June 2009.

Silva LMM, Figueirêdo RMF, Sousa FC, Sousa EP, Lima AKVO (2011) Parâmetros químicos, físicos e físico-químicos de três variedades de melão. Revista Verde. 6(5): 242-246.

Silva ML, Queiróz MA, Ferreira MAJ, Aragão CA (2007) Variabilidade genética de acessos de melancia coletados em três regiões do estado da Bahia. Revista Caatinga. 20(4): 93-100.

Souza Leão PC, Silva DJ, Silva EEG (2005) Efeito do ácido giberélico, do bioestimulante $\mathrm{Crop} \mathrm{Set}^{\circledR}$ e do anelamento na produção e na qualidade da uva 'thompson seedless' no vale do São Francisco. Revista Brasileira de Fruticultura. 27(3): 418-421.

Stadnik MJ, Talamini V (2004) Extratos vegetais e de algas no controle de doenças de plantas. In: Stadnik MJ, Talamini V (eds) Manejo ecológico de doenças de plantas. Florianópolis: Universidade Federal de Santa Catarina, 3, p.45-62, 2004.

Stirk WA, Novak MS, Van Staden J (2003) Cytokinins in macroalgae. Plant Growth Regulation. 41: 13-24.

Torres SB (2007) Germinação e desenvolvimento de plântulas de melancia em função da salinidade. Revista Brasileira de Sementes. 29(3): 77-82

Ugarte RA, Sharp G, Moore B (2006) Changes in the brown seaweed Ascophyllum nodosum (L.) Le Jolis. Plant morphology and biomass produced by cutter rake harvests in southern New Brunswick, Canada. Journal of Applied Phycology. 18(3-5): 351-359.

Yemn EW, WILLIS AJ (1954) The estimation of carbohydrate in plant extracts by anthrone. Biochemical Journal. 57(1): 508-514. 